\title{
Physico-Chemical Analysis of Korapuzha River and
}

\section{Estuaries}

\author{
Subburaj $\mathrm{M}^{1}$, Mity Thambi ${ }^{2}$ and Mahesh $\mathrm{G}^{3}$ \\ 1. Jr. Research Officer, Government of Kerala, RAL, Calicut, Kerala 673009, India \\ 2. Department of Chemistry, University of Calicut, Keral, 673635, India \\ 3. R\&D Department, Eureka Forbes Ltd, Bangalore, Karnataka, India
}

\begin{abstract}
Korapuzha is a short river of $40 \mathrm{~km}$ with a drainage area of $624 \mathrm{~km}^{2}$, flowing from dense forest and empties into the Arabian sea. It is formed by the confluence of two streams Agalapuzha and Punnoorpuzha. In this study the samples were collected from Agalapuzha, Punnoorpuzha and Korappuzha, Korapuzha estuaries. The temperature and pH were monitored on the site and the remaining parameters were analyzed in the laboratory. The physical quality parameters such as color, odor, appearance and chemical quality parameters such as $\mathrm{pH}$, alkalinity, chloride, nitrate, nitrite, sulphate, ammonia, dissolved oxygen, total solids, total hardness, and iron have been evaluated. Compare the physical and chemical parameters. The physico-chemical analysis shows that the samples have high level of salinity, sulphate, total solids and total hardness. The results show that the water is affected by the intrusion of sea water into the river by excess excavation of sands from river for the construction of buildings and other anthropogenic activities which leads to environmental destruction.
\end{abstract}

Key words: Korapuzha River, physico-chemical, pollution, degradation.

\section{Introduction}

Water is most essential for the survival of any form of life. Water sources available for drinking and other domestic purpose must possess high degree of purity, free from chemical and microbial contamination [1]. The quality of water is getting vastly deteriorated due to inadequate management of water resources, unscientific waste disposal, improper water management and carelessness towards environment, which has led to scarcity of potable water affecting the human health. There are enormous numbers of natural and manmade water bodies which are used for drinking and irrigation purpose. However, in recent years due to rapid urbanization, industrialization and modern agricultural activities the quality of water bodies deteriorated causing environmental hazards. Due to the growth of population and man-made activities, the quality of water is deteriorating

Corresponding author: Subburaj M, Ph.D., research fields: water chemistry, environmental science and material science. Email: subujob@gmail.com. everywhere [2]. One of the most severe problems is high concentration of salts in soils and water resources [3]. Thus, water quality and its management have received much attention in developing countries. The governments took severe efforts to fulfill the task.

Korapuzha is a river which flows through the Kozhikode district of Kerala state in India. It is formed by the confluence of two streams, Agalapuzha and Punnoorpuzha. It is originated in the mountains of Wayanad district and utilized by many villages for irrigation, drinking and domestic purposes. The Korapuzha empties into the Arabian Sea at Elathur after flows $40 \mathrm{~km}$ with a drainage area of $624 \mathrm{~km}^{2}$ (241 sq mi). The Korapuzha is generally considered as the cordon sanitaire between the historic important place of North and South Malabar in the erstwhile Malabar District. The river sides fully enclosed with flora, fauna and mangroves. The rapid urbanization and developments in this area raise threatening to the environment. 


\section{Materials and Methods}

Rapid population growth developments, urbanization and encroachments change the ecological and environmental conditions in this area which is disturbing the water quality. The present study aims to check the present status of Korapuzha water quality. Sampling stations were identified from Korapuzha estuaries, Korapuzha and the two main streams of Korapuzha known as Agalapuzha and Punnoorpuzha. The samples for analysis were collected in a two liter sterilized bottles using the standard procedure for grab or catch samples in accordance with standard methods of APHA-2005[4]. The samples were labeled and transported to the laboratory as earlier as possible. All the chemicals and reagents used were of analytical grade. Double distilled water was used for the preparation of solutions.

\section{Results and Discussion}

The physicochemical parameters of water were analyzed using standard methods given in APHA-2005 [4] and presented in Table 1.

\subsection{Temperature}

Temperature of water is basically important because it affects bio-chemical reactions in aquatic organisms. A rise in temperature of water leads to the speeding up of chemical reactions in water, reduces the solubility of gases and amplifies the tastes and odor. In the present study temperature was ranged between 22.05 to $29.58{ }^{\circ} \mathrm{C}$ which was within the range of 25 and 30 ${ }^{\circ} \mathrm{C}$ needed by fish [5].

\section{$3.2 \mathrm{pH}$}

$\mathrm{pH}$ is one of the most important factors that severs as an index for the pollution. The average $\mathrm{pH}$ value of the rainwater was 5.10. Higher values of $\mathrm{pH}$ hasten the scale formation in water heating apparatus and also reduce germicidal potential of chloride. High $\mathrm{pH}$ induces the formation of trihalomethane which is toxic [6]. In the present study $\mathrm{pH}$ values were within the prescribed limit of standards.

\subsection{Alkalinity}

Alkalinity value less than $100 \mathrm{mg} /$ liter is desirable for domestic use. However, in large quantities it imparts bitter taste to water. In the present investigation the total alkalinity of the water samples is found in the range 20.8 to $102.8 \mathrm{mg} / \mathrm{liter}$.

\subsection{Chloride}

Chloride occurs in all types of natural waters. The high concentration of chloride is considered to be an indication of pollution due to high organic waste of animal origin [7].

Chloride values obtained in the study are found to

Table 1 The physicochemical parameters of water using standard methods given in APHA-2005.

\begin{tabular}{lllll}
\hline Parameters & $\begin{array}{l}\text { Korapuzha } \\
\text { Estuaries }\end{array}$ & Korapuzha River & Punnoor Puzha & Agalapuzha \\
\hline $\mathrm{pH}$ & 7.2 & 7.1 & 6.9 & 6.9 \\
Alkalinity & 102.3 & 96.5 & 20.8 & 22.3 \\
Chloride & 20,400 & 15,400 & 8.6 & 12.4 \\
Nitrate & $\mathrm{ND}$ & $\mathrm{ND}$ & $\mathrm{ND}$ & $\mathrm{ND}$ \\
Nitrite & $\mathrm{ND}$ & $\mathrm{ND}$ & $\mathrm{ND}$ & $\mathrm{ND}$ \\
Ammonia & $\mathrm{ND}$ & $\mathrm{ND}$ & $\mathrm{ND}$ & $\mathrm{ND}$ \\
Sulphate & 2,500 & 2,500 & $\mathrm{ND}$ & $\mathrm{ND}$ \\
DO & 7.6 & 7.5 & 6.1 & 6.1 \\
TDS & $34,089.1$ & $25,718.5$ & 102.8 & 113.6 \\
Hardness & $5,800.9$ & $2,600.4$ & 24.7 & 30.8 \\
Iron & 0.5 & 0.6 & 0.3 & 0.3 \\
\hline
\end{tabular}

ND—Not detectable. 
Table 2 Permissible values of various pollutants for drinking water (mg/Liter except pH).

\begin{tabular}{lllllllllll}
\hline \multirow{2}{*}{ Quality } & \multicolumn{3}{c}{ Sample range } & \multicolumn{3}{c}{ WHO limit } & \multicolumn{3}{c}{ USEPA } & \multicolumn{3}{c}{ CPCB } & \multicolumn{2}{c}{ IS-10500 } \\
\cline { 2 - 11 } & Min & Max & Min & Max & Min & Max & Min & Max & Min & Max \\
\hline pH & 6.9 & 7.2 & 7.0 & 9.2 & 6.5 & 8.5 & 6.5 & 8.5 & 6.5 & 8.5 \\
Alkalinity & 20.8 & 102.3 & - & 200 & - & 200 & - & 200 & - & 200 \\
Chloride & 8.6 & 20,400 & 200 & 600 & - & 250 & & & & \\
Nitrate & 0 & 0 & - & 45 & - & 45 & - & 20 & - & 45 \\
Nitrite & 0 & 0 & 0 & 0 & 0 & 0 & 0 & 0 & 0 & 0 \\
Ammonia & 0 & 0 & 0 & 0 & 0 & 0 & 0 & 0 & 0 & 0 \\
Sulphate & 0 & 2,500 & - & 200 & - & 400 & - & 200 & - & 200 \\
DO & 6.1 & 7.6 & & & & & - & 6.0 & - & - \\
TDS & 102.8 & 34,089 & 500 & 1500 & - & 500 & - & 500 & - & 500 \\
Hardness & 24.7 & 5,801 & 100 & 500 & - & - & - & 300 & - & 300 \\
Iron & 0.3 & 0.6 & 0.1 & 1.0 & 0.1 & 1.0 & 0.1 & 1.0 & 0.1 & 1.0 \\
\hline
\end{tabular}

be high in Korapuzha and Korapuzha kuniyil kadavu compared with the stream which have 8.6-12.4 mg/liter which is within permissible levels. The Korapuzha and Korapuzha kuniyil kadavu have in the range between 15,400-20,400 mg/liter.

\subsection{Nitrate, Nitrites and Ammonia}

Nitrate is the most important nutrient in an ecosystem. Generally water bodies polluted by organic matter exhibit higher values of nitrate. Moreover nitrogen is an essential nutrient that is required by all plants and animals for the formation of amino acids. In its molecular form, nitrogen cannot be used by most aquatic plants, therefore it must be converted to another form. One such form is ammonia $\left(\mathrm{NH}_{3}\right)$. Ammonia may be taken up by plants or oxidized by bacteria into nitrate $\left(\mathrm{NO}_{3}{ }^{-}\right)$or nitrite $\left(\mathrm{NO}_{2}\right)$. Of these two forms, nitrate is usually the most important. However, it is very difficult to directly measure nitrate. A common procedure for measuring nitrate is to first measure the amount of nitrite in a sample. Then, reduce any nitrate in the sample to nitrite. Lastly, measure the combined nitrite (the initial nitrite plus the reduced nitrate) concentration. By subtracting the original nitrite concentration from the combined nitrite concentration, one can determine the amount of nitrate that was in the sample. Although nitrogen is an essential nutrient for all aquatic plants and animals, it is possible to have too much of a good thing. Excessive concentrations of nitrogen can lead to eutrophication and subsequent degradation of stream water quality. In addition, if water containing nitrate levels greater than $10 \mathrm{mg} \mathrm{NO}_{3}-\mathrm{N} /$ liter is used to prepare infant formula, it can result in methemoglobinemia. Common sources of excessive nitrogen include sewage and agricultural wastes. Elevated stream water nitrogen levels may indicate the presence of one or both of these forms of pollution. In the present study the concentration of nitrate, nitrite and ammonia have not detected [8].

\subsection{Sulphate}

Sulphate ion does not affect the taste of water, sulphate ion concentration in the present investigation varied from 2,500 mg/liter. Sea water contains about 2,700 mg/liter sulfate [9]. According to GEMS/Water, a global network of water monitoring stations, typical sulfate levels in fresh water are in the vicinity of 20 $\mathrm{mg} / \mathrm{liter}$ and range from 0 to $630 \mathrm{mg} / \mathrm{liter}$ in rivers (the highest values are found in Belgium and Mexico), from 2 to $250 \mathrm{mg} / \mathrm{liter}$ in lakes (the highest value is found in Mexico) and from 0 to $230 \mathrm{mg} / \mathrm{liter}$ in groundwater (the highest values are found in Chile and Morocco) [10].

\subsection{Dissolved Oxygen}

It is an important parameter which is essential to the metabolism of all aquatic organisms having aerobic 
respiration. Presence of Dissolved Oxygen in water may be due to direct diffusion from air and photosynthetic activity of autotrophs. Oxygen can be rapidly removed from the waters by discharge of oxygen demanding wastes. The Dissolved Oxygen values obtained in the present study are within permissible standards.

\subsection{Total Dissolve Solids}

Total dissolved solids values ranged within 34,089 to $25,719 \mathrm{mg} / \mathrm{liter}$ in Korapuzha and Korapuzha kuniyil kadavu compared with the stream which has 103-114 mg/liter. As per standards and in this respect this water is highly polluted.

\subsection{Hardness}

Hardness is a measure of the ability of water to cause precipitation of insoluble calcium and magnesium salts of higher fatty acids from soap solutions. The hardness causing ions are calcium, magnesium bicarbonate, carbonate, chloride and sulphates. The hardness values of the present study were found to range between 5,800 to 2,600 mg/liter in Korapuzha and Korapuzha kuniyil kadavu compared with the stream which have 24 and 30 $\mathrm{mg} / \mathrm{liter}$. The quantities of calcium in natural water depend up on the type of rocks. Small concentration of calcium is beneficial in reducing the corrosion in water pipes. Magnesium hardness particularly associated with sulphate ion has laxative effect on persons UN (United Nations) accustomed to it [11].

\subsection{Iron}

Iron is seldom found at concentrations greater than 10 milligrams per liter or 10 parts per million. However, as little as $0.3 \mathrm{mg} / \mathrm{liter}$ can cause water to turn a reddish brown color. Iron is mainly present in water in two forms: either the soluble ferrous iron or the insoluble ferric iron. Water containing ferrous iron is clear and colorless because the iron is completely dissolved. Iron is not hazardous to health, but it is considered a secondary or aesthetic contaminant. In the present study the concentration of iron is in the prescribed limit.

\section{Conclusion}

The observation in this study indicates that the higher values of chloride, total dissolved solids, sulphates and hardness show that the water is highly polluted by some external sources and the intensity of pollution is gradually spread towards the upstream. The pollution may be due to the unplanned development and unscientific way of excavation, anthropogenic activities and other developments near the river and estuaries which lead to the intrusion of sea water in to the river.

\section{Reference}

[1] Borul, S. B., and Banmeru, P. K. 2012. "Physiochemical Analysis of Ground Water for Drinking from Selected Sample Points around the Manmeru Science College, Lonar Buldana District of Maharashtra." Journal of Chemical and Pharmaceutical Research (5): 2603-6.

[2] Bhadja, P., and Vaghela, A. 2013. "Status of River Water Quality of Saurashtra, Gujarat, India.” International Journal of Advanced Biological Research (2): 276-80.

[3] Dutta, S., and Chowhan, P. 2005. "Assessment of Groundwater Quality of Masuda Tehsil, Ajmer District, Rajasthan.” The Ecoscan (3\&4): 281-4.

[4] APHA. 2005. Standard Methods for Examination of Water and Waste Water, 21st Edition, Washington D.C

[5] Brown, R. M., Cleiland, N. J. Mc., Deiniger, R. A., and O' Connor, M. F. A. 1972. "Water Quality Index-Crossing the Physical Barrier (Jenkis, S H ed).” In Proceedings of Intl. Conf. on Water Poll, 787-97.

[6] Trivedi, R. K., and Goel, P. K. 1986. Chemical and Biological Methods for Water Pollution Studies. Karad: Environ Publications.

[7] Singh, S., Gupta, R. P., and Mathur, R. 2013. "Status of the Drinking Water Quality in School of Datia Town (M.P.)." International Journal of Plant, Animal and Environmental Sciences (1): 56-61.

[8] Subburaj Mookkaiah. 2012. Toxicology of Rain Water: Multi-dimensional Analysis. Germany: Lap Lambert Academic Publications.

[9] Hitchcock, D. R. 1975. "Biogenic Contribution to Atmospheric Sulfate Levels, Water's Interface with 
Energy, Air and Solids.” In Proceedings of the Second National Conference on Complete Water-Reuse, 291-310.

[10] United States Environment Program, Global Environmental Monitoring System: Freshwater Quality
Program (GEMS). "Salts and Salinization of Surface Waters.” Accessed at May 5th, 2015. http:// www. gemswater.org/atlas-gwq/salts-e.html.

[11] Khursid. S., Zaheeruddin, A., and Basheer. 1998. Ind.J.Env. Prot. 18 (4):246-9. 